\title{
Pengaruh Konsentrasi Logam Berat Zn pada Pertumbuhan Mikroalga Dunaliella salina (Chlorophyceae: Dunaliellaceae)
}

\author{
Angelina Yusniar Christanty Sihotang*, Gunawan Widi Santosa, Sunaryo \\ Departemen IImu Kelautan, Fakultas Perikanan dan IImu Kelautan, Universitas Diponegoro \\ JI. Prof. H. Soedarto S. H, Tembalang, Semarang, Jawa Tengah 50275 Indonesia \\ ${ }^{*}$ Corresponding author, e-mail : angelina.zihotang@gmail.com
}

\begin{abstract}
ABSTRAK: Logam berat $\mathrm{Zn}$ merupakan salah satu logam berat essensial yang dibutuhkan tumbuhan dalam jumlah sedikit, termasuk mikroalga Dunaliella salina. Konsentrasi logam pada media kultur diduga berpengaruh terhadap pertumbuhan dan kandungan proksimatnya. Tujuan penelitian ini adalah mengetahui pertumbuhan dan kandungan proksimat pada mikroalga Dunaliella salina pada konsentrasi logam berat $\mathrm{Zn}$ yang berbeda. Materi yang digunakan dalam penelitian ini adalah mikroalga $D$. salina yang diperoleh dari stok murni Laboratorium Balai Besar Pengembangan Budidaya Air Payau (BBPBAP) Jepara. Hasil penelitian menunjukkan penambahan konsentrasi logam berat $\mathrm{Zn}$ yang berbeda pada media tidak berpengaruh terhadap laju pertumbuhan $D$. salina $(\mathrm{p} \geq 0,05)$.
\end{abstract}

Kata Kunci : Dunaliella salina; Pertumbuhan; Zn

\section{The Effect of Heavy Metal Zn Concentration on the Growth of Microalgae Dunaliella salina (Chlorophyceae: Dunaliellaceae)}

ABSTRAK: Heavy metal $\mathrm{Zn}$ is one of the essential heavy metals needed by plants in small amounts, including the microalgae Dunaliella salina. Metal concentration in the living medium is thought to have an effect on growth and proximate content. The purpose of this study was to determine the growth and proximate content of green microalgae $D$. salina at different concentrations of heavy metal $\mathrm{Zn}$. The material used in this study was $\mathrm{D}$. salina microalgae obtained from pure stock from the Laboratory of the Center for Brackish Water Cultivation Development (BBPBAP) Jepara. The results showed that the addition of different heavy metal concentrations affected the growth cellular counts at the last expontial phase, though it did not affect the cellular growth rate of $D$. salina at $(p \geq 0,05)$.

Keywords: Dunaliella salina; Growth; Zn.

\section{PENDAHULUAN}

Keberadaan limbah logam berat telah menjadi masalah yang cukup serius dalam lingkungan. Pembuangan limbah yang terus menerus dikhawatirkan akan menimbulkan akumulasi pencemaran logam berat. Dalam suatu perairan, pencemaran yang disebabkan oleh logam berat dapat menimbulkan banyak masalah baik yang bersifat sementara maupun yang berkepanjangan. Kamaruzzaman et al. (2011), menyatakan bahwa, semakin tinggi tingkat kadar logam pada perairan maka akan berpengaruh terhadap keseimbangan ekologi dengan mengubah berbagai organisme yang hidup dalam air.

Mikroalga mampu secara selektif menyerap dan menjerap logam dari media cair dan mengakumulasi logam tersebut dalam selnya (Aunurohim dan Kurniawan, 2014). Logam berat Zn merupakan salah satu logam berat essensial yang dibutuhkan hampir semua tumbuhan dalam jumlah sedikit, namun jika jumlahnya melebihi batas ambang yang telah ditentukan maka akan membahayakan bagi kehidupan organisme itu sendiri dan bersifat toksik. Bagi tanaman fungsi $\mathrm{Zn}$ adalah terlibat dalam beberapa fungsi enzim untuk meningkatkan reaksi-reaksi metabolik, sintesis senyawa-senyawa pertumbuhan tanaman, memproduksi klorofil dan karbohidrat (Ratmini, 2014). Dunaliella salina merupakan kelompok alga hijau yang mempunyai kandungan protein, lemak, dan 
karbohidrat sebagai sumber pangan (Darsi et al., 2012). Smith (2010), menyatakan bahwa Dunaliella salina merupakan fitoplankton yang mampu bertahan hidup dalam lingkungan yang memiliki kadar garam tinggi. Berdasarkan latar belakang diatas, maka penelitian ini bertujuan untuk mengetahui pengaruh pertumbuhan pada mikroalga hijau Dunaliella salina pada konsentrasi logam berat $\mathrm{Zn}$ yang berbeda.

\section{MATERI DAN METODE}

Materi yang dipergunakan dalam penelitian adalah mikroalga Dunaliella salina yang diperoleh dari stok murni Laboratorium Balai Besar Pengembangan Budidaya Air Payau (BBPBAP) Jepara. Penelitian ini dilaksanakan pada bulan Juni sampai Juli 2020 di Laboratorium Mikroalga yang merupakan bagian dari Laboratorium Biologi Laut, Departemen IImu Kelautan Fakultas Perikanan dan Ilmu Kelautan, Universitas Diponegoro, Semarang.

Metode penelitian yang diterapkan adalah eksperimen laboratoris. Rancangan penelitian yang digunakan adalah Rancangan Acak Lengkap (RAL) dengan 4-perlakuan dan 3 kali ulangan. Perlakuan yang berupa pemberian penambahan senyawa Zn kedalam media kultur mikroalga $D$. salina dengan konsentrasi yang berbeda (1 ppm, 3 ppm dan 5 ppm). Kultur Dunaliella salina dilakukan dengan menggunakan 12 wadah dengan volume 3 liter. Kultur dilengkapi dengan aerasi dan pencahayaan lampu TL $36 \mathrm{~W}$. Senyawa yang dipakai adalah $\mathbf{Z n C l}_{\mathbf{2}}$.

Persiapan kultur dimulai dengan sterilisasi peralatan, yaitu toples kaca dengan penutupnya dan selang aerasi dicuci bersih dengan menggunakan sabun kemudian dikeringkan dan dibersihkan dengan alkohol $70 \%$. Sterilisasi bahan, dilakukan dengan menambahkan kaporit sebanyak 1,2 g ke dalam 20 liter air laut dan diaerasi selama 1 × 24 jam. Sebelum ditambahkan Na-Thiosulfat sebanyak 0,6 g selama 6 jam. Kemudian air laut disaring dengan menggunakan kain kassa dan dimasukkan ke dalam panci dengan penutupnya dan disterilkan dengan cara merebus hingga mendidih \pm 30 menit. Air laut yang sudah dingin dan steril diencerkan sampai bersalinitas 30 ppt bersama peralatan kultur kemudian disinari lampu UV \pm 1 jam.

Larutan $\mathrm{Zn}$ yang dibuat yaitu larutan stok dengan konsentrasi 1, 3 dan 5 ppm. Senyawa $\mathrm{ZnCl}_{2}$ yang digunakan sebagai larutan stok pada penelitian ini adalah $\mathrm{ZnCl}_{2}$. Larutan stok dengan $100 \mathrm{ppm}$ dibuat dengan cara menimbang $\mathrm{ZnCl}_{2}$ sebanyak $0,21 \mathrm{~g}$ yang kemudian dilarutkan ke dalam $1 \mathrm{~L}$ akuades. Larutan stok Zn dilakukan dengan cara pengenceran.

Sebanyak $5 \mathrm{~mL}$ sampel alga diambil menggunakan pipet setiap pagi jam 08.30 WIB untuk perhitungan kepadatan. Sampel yang telah diambil dimasukkan dalam botol vial volume $10 \mathrm{~mL}$ sampai dianalisis secara mikroskopik menggunakan haemocytometer. Pemanenan keseluruhan biomassa dilakukan pada kultur mikroalga yang telah memasuki fase stasioner yaitu pada hari ke-9.

\section{HASIL DAN PEMBAHASAN}

Kepadatan sel mikroalga dalam kultur dapat ditandai dengan bertambahnya jumlah sel yang dapat dilihat pada Gambar 1. Sementara itu laju pertumbuhan mikroalga disajikan pada Gambar 2. Pada Gambar 1 menunjukkan bahwa pada perlakuan kontrol $(0 \mathrm{ppm})$ dan 5 ppm sel Dunaliella salina mengalami fase eksponensial pada hari ke-0 sampai hari ke-8. Pada perlakuan 1 ppm sel alga mengalami fase eksponensial pada hari ke-0 sampai hari ke-7. Sementara itu, mikroalga pada perlakuan 3 ppm mengalami fase eksponensial pada hari ke-0 sampai hari ke- 9 .

Kepadatan sel pada saat puncak hari ke-8 tertinggi pada perlakuan kontrol $\left(1,590 \times 10^{4}\right.$ $\mathrm{sel} / \mathrm{mL})$, kemudian pada perlakuan $1 \mathrm{ppm}\left(929 \times 10^{4} \mathrm{sel} / \mathrm{mL}\right)$, perlakuan $3 \mathrm{ppm}\left(1,161 \times 10^{4} \mathrm{sel} / \mathrm{mL}\right)$ dan kepadatan sel pada perlakuan $5 \mathrm{ppm}\left(818 \times 10^{4} \mathrm{sel} / \mathrm{mL}\right)$. Hal ini menandakan bahwa seiring dengan bertambahnya konsentrasi $\mathrm{Zn}$ pada perlakuan menyebabkan semakin menurun jumlah kepadatan selnya. Dalam penelitian ini penambahan $\mathrm{Zn}$ berpengaruh terhadap kepadatan populasi dari mikroalga Dunaliella salina tersebut $(p<0,05)$. Menurut Kaplan et al. (1995), yang menyatakan bahwa pada kultur mikroalga hijau Chlorela sp. yang diberikan paparan logam berat menunjukkan jumlah sel semakin meningkat setiap hari hingga waktu 6 hari, namun populasinya akan menurun seiring dengan meningkatnya konsentrasi logam berat.

Gambar 2 menunjukkan laju pertumbuhan eksponensial $(\mu)$ mikroalga Dunaliella salina pada masing-masing perlakuan. Pada perlakuan kontrol $(0 \mathrm{ppm})$ sebesar 0,368 , pada perlakuan $1 \mathrm{ppm}$ 
sebesar 0,366, pada perlakuan 3 ppm, sebesar 0,292 dan perlakuan 5 ppm, sebesar 0,296. Meskipun hasil analisis variannya, menunjukkan bahwa penerapan konsentrasi Zn dalam media kultur yang berbeda tidak menunjukkan adanya perbedaan pengaruh terhadap laju pertumbuhan mikroalga Dunaliella salina $(p \geq 0,05)$. Namun hasil ini menunjukkan, bahwa dengan semakin besar konsentrasi $Z n$ yang diberikan semakin menurunkan laju pertumbuhannya $(y=-0,0171 x+0,3689$; $\left.R^{2}=0,316\right)$. Hal ini diduga bahwa penambahan logam $\mathrm{Zn}$ dalam penelitian ini belum melebihi ambang batas dari kebutuhan logam Zn dalam mikroalga. Kematian alga terjadi pada kadar logam maksimal Zn $10 \mathrm{mg} / \mathrm{L}$ (Purnawati et al., 2015). Unsur Zn pada tumbuhan sangat penting dalam proses pembentukan klorofil bagi aktivitas fotosintesis. Proses metabolisme yang terjadi dalam fotosintesis melibatkan reaksi-reaksi kimia dengan bantuan enzim yang berfungsi sebagai katalisator. Salah satu enzim yang penting bagi proses fotosintesis diatom laut adalah enzim Carbonic Anhydrase (CA). Enzim Carbonic Anhydrase (CA) yang terdapat dalam ion seng merupakan salah satu enzim yang penting bagi proses fotosintesis diatom laut yang berperan

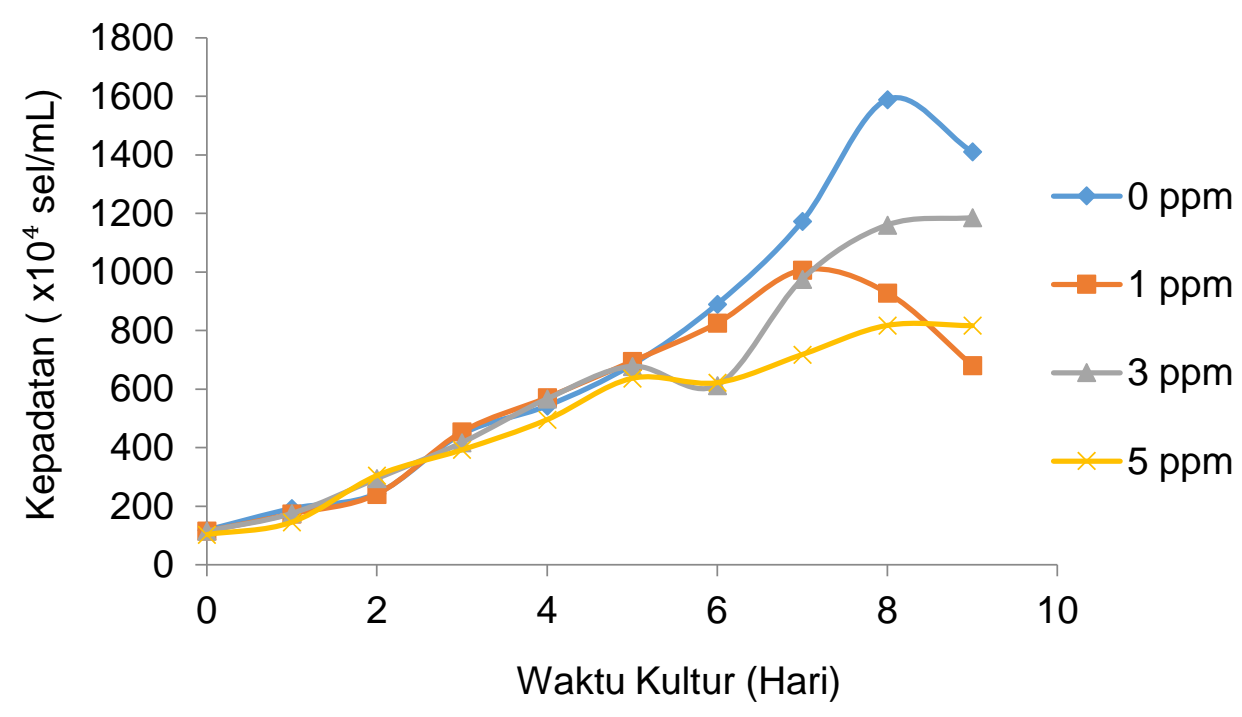

Gambar 1. Kepadatan sel Dunaliella salina yang dikultur selama 9 hari pada media dengan penambahan $\mathrm{Zn}$ yang berbeda

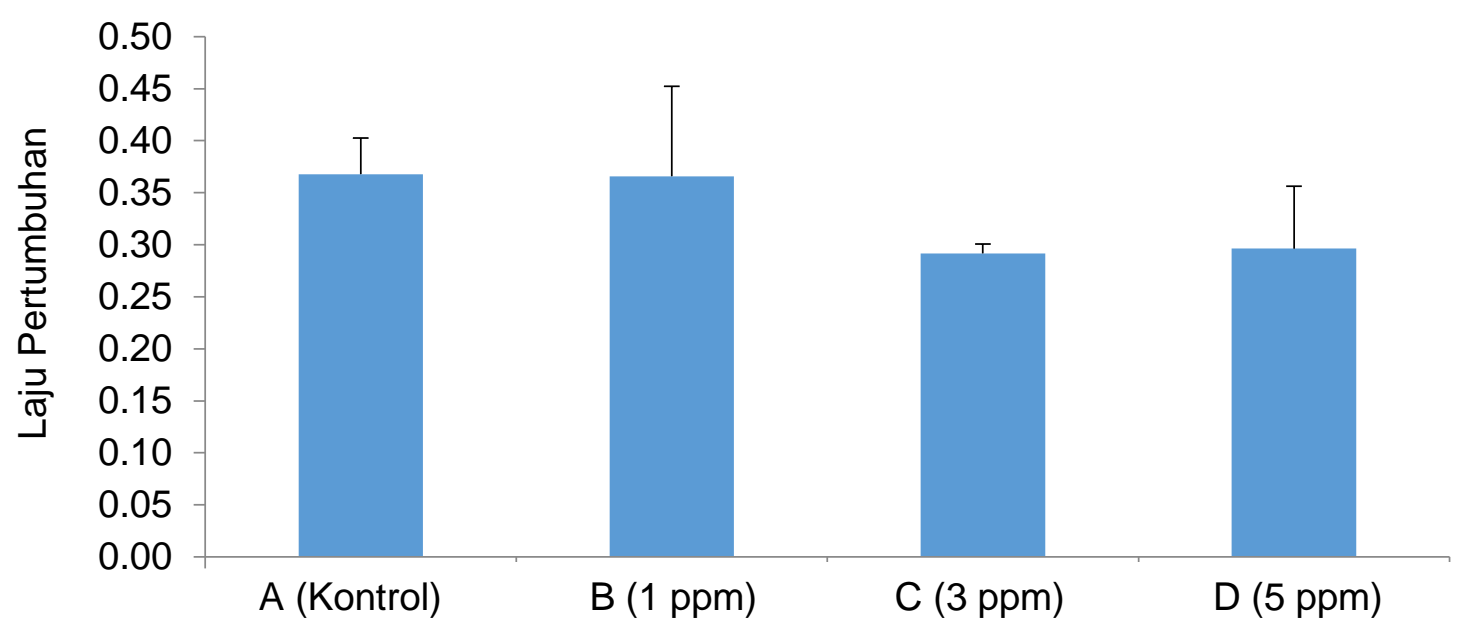

Perlakuan Penambahan Konsentrasi Zn

Gambar 2. Laju Pertumbuhan Dunaliella salina pada media yang ditambahkan Zn yang berbeda. 
dalam mengubah asam karbonat $\left(\mathrm{HCO}_{3}\right)$ menjadi $\mathrm{CO}_{2}$ (Darmono, 1995). $\mathrm{CO}_{2}$ merupakan sumber karbon utama pada proses fotosintesis bagi mikroalga yang cukup tersedia, sehingga dalam proses metabolisme dapat berlangsung cepat dan kerapatan sel meningkat (Prihantini et al., 2005). Logam berat diketahui menghambat enzim protochiorofillide reductase yang mengaktivasi protoklorofil menjadi klorofil. Kondisi lingkungan yang terkandung logam berat merupakan salah satu faktor penghambatan aktivitas fotosintesis. Terhambatnya aktifitas dalam fotosintesis karena terjadi penghancuran pigmen-pigmen dalam kloroplas yang berfungsi untuk menyerap cahaya serta penghambatan enzim-enzim kunci yang terlibat dalam fiksasi $\mathrm{CO}_{2}$ (De Fillipis dan Pallaghy, 1994). Dimana proses fiksasi $\mathrm{CO}_{2}$ dapat mengurangi sintesis ATP dan NADPH yang berdampak pada laju fotosintesis. Terganggunya aktivitas fotosintesis ini menyebabkan kemampuan memperbanyak diri menjadi berkurang sehingga menyebabkan pertambahan jumlah selnya menjadi terhambat (Ernest, 1998). Tripathi dan Gaur (2006), menyatakan bahwa Cu dan Zn menurunkan kandungan protein, karbohidrat, pigmen fotosintesis, metabolisme nitrat serta respirasi dan pertumbuhan pada beberapa algae hijau, yaitu Scenedesmus sp.

Logam Zn merupakan logam essensial yang dibutuhkan tumbuhan pada konsentrasi tertentu (Ratmini, 2014). Di perairan Zn biasa dihasilkan dari industri karet dan cat. Kematian alga terjadi pada kadar logam maksimal, seperti Cu maksimal $18 \mathrm{mg} / \mathrm{L}$, sedangkan Cd. Cr dan Zn maksimal 10 mg/L (Purnawati et al., 2015). Menurut Hala et al., (2012), untuk mempertahankan kehidupannya, mikroalga umumnya memiliki mekanisme perlindungan terhadap logam beracun. Mekanisme ini melibatkan pembentukan kompleks logam dengan protein dalam membran sel, sehingga logam dapat terakumulasi dalam sel tanpa mengganggu pertumbuhannya. Sedangkan ketika konsentrasi logam tinggi, sistem perlindungan organisme tidak mampu lagi mengimbangi efek toksik logam, sehingga dapat menghambat pertumbuhan selnya. Hal ini dapat membuktikan bahwa penambahan logam berat Seng $(Z n)$ mempengaruhi pertumbuhan biomassa mikroalga Dunaliella salina. Namun dalam jumlah yang sangat sedikit $Z n$ dapat berperan dalam mendorong pertumbuhan. Penambahan logam $Z n$ tidak berpengaruh terhadap laju pertumbuhannya $(p \geq 0,05)$.

Pada pertumbuhan mikroalga $D$. salina, kualitas air sangat penting selama kultur. Nilai kisaran salinitas $(30 \mathrm{ppt})$, suhu $\left(25-26^{\circ} \mathrm{C}\right)$, dan $\mathrm{pH}(7-8)$ selama penelitian ini masih berada pada kisaran optimum (Kusdarwati et al., 2011; Tafreshi dan Shariati, 2009; Shabana dan Mohammad, 2016)-dan perubahan terjadi bukan merupakan faktor pembatas utama pada pertumbuhan mikroalga Dunaliella salina.

\section{KESIMPULAN}

Sel Dunaliella salina tumbuh di semua level konsentrasi yang diberikan dalam penelitian ini. Penambahan konsentrasi logam berat $\mathrm{Zn}$ pada media kultur yang berbeda mempengaruhi kepadatan dari mikroalga Dunaliella salina $(p<0,05)$. Namun tidak berpengaruh terhadap laju pertumbuhannya $(p \geq 0,05)$. Laju pertumbuhan dari yang tertinggi ke terendah terdapat pada kontrol, yaitu sebesar 0,368 diikuti perlakuan 1 ppm $(0,366)$ diikuti oleh perlakuan 3 ppm $(0,292)$ dan perlakuan $5 \mathrm{ppm}(0,296)$.

\section{DAFTAR PUSTAKA}

Aunurohim, A. \& Kurniawan, J.I., 2014. Biosorpsi Logam Zn2+ dan Pb2+ oleh Miroalga Chlorella sp.. Jurnal Sains dan Seni Pomits, 3(1):p.15375.

Budi, M.R.S., Rahardja, B.S. \& Masithah, E.D., 2018. Potensi Penurunan Konsentrasi Logam Berat Tembaga $(\mathrm{Cu})$ dan Pertumbuhan Mikroalga Spirulina plantesis pada Media Kultur. Jurnal Akuakultur Rawa Indonesia, 6(1):83-93. DOI: 10.36706/jari.v6i1.7152.

Darmono. 1995. Logam dalam system biologi makhluk hidup. Jakarta, Universitas Indonesia, 25 hal.

Darsi, R., Supriadi, A., \& Sasanti, A.D., 2012. Karakteristik Kimiawi dan Potensi Pemanfaatan Dunaliella salina dan Nannochloropsis sp. Fishtech, 1(1):14-25. DOI: 10.36706/fishtech. v1i1.802.

De-Filippis, L.F., \& Pallaghy, C., 1994. Heavy metals: sources and biological effects. Health and Environmental Research Online, 42:31-77. 
Dewi, N.K., 2017. Monograf metallothionein. Fakultas Matematika dan Ilmu Pengetahuan Alam, Universitas Negeri Semarang, $53 \mathrm{hlm}$.

Ernest, W.H.O., 1998. Effects of heavy metals in plants at the cellular and organismic level, in : ecotoxicology. Gerrit Schuurmann and Bernd Markert (Eds) John Wiley and Sons, Inc and Spektrum Akedemischer Verlag, 587-620.

Hala, Y., Suryati, E. \& Taba, P. 2012. Biosorpsi Campuran Logam $\mathrm{Pb}^{2+}$ dan $\mathrm{Zn}^{2+}$ oleh Chaetoceros cacitrans. Chemistry Progress, 5(2):86-92. DOI: 10.35799/cp.5.2.2012.772.

Kamaruzzaman, B.Y., Rina, Z., John, B.A. \& Jalal, K.C.A., 2011. Heavy Metal Accumulation in Commercially Important Fsihes of South West Malaysian Coast. Research Journal of Environmental Sciences, 5(6):595-602. DOI: 10.3923/rjes.2011.595.602.

Kaplan, D., Heimer, Y.M., Abeliovich, A. \& Goldsbrough, P., 1995. Cadmium toxicity and resistance in Chlorella sp. Elsevier Plant Science, 109:129-137.

Kawaroe, M., Prartono, T., Sunuddin, A., Sari, D.W., \& Augustine, D., 2010. Mikroalga: Potensi dan pemanfaatannya untuk Produksi Bio Bahan Bakar. Penerbit Institut Pertanian Bogor Press. Bogor. $150 \mathrm{hlm}$.

Kusdarwati, R., Mustofa, A., \& Rahardja, B.S., 2011. Pengaruh Penambahan Vitamin $\mathrm{B}_{12}$ pada Media Blotong Kering terhadap Pertumbuhan Populasi Dunaliella salina. Jurnal IImiah Perikanan dan Kelautan, 3(1): 73-77. DOI : 10.20473/jipk.v3i1.11628

Prihantini, N.B., Damayanti, D. \& Yuniati, R., 2005. Pertumbuhan Chlorella sp. dalam Medium Ekstrak Tauge (MET) dengan variasi pH awal. Makara, 9(1):1-6.

Purnawati, F.S., Soeprobowati, T.R. \& Izzati, M., 2015. Potensi Chlorella vulgaris Beijerinck dalam Remediasi Logam Berat Cd dan Pb Skala Laboratorium. Biorma, 16(2):102-113. DOI: 10.14710/bioma.16.2.102-113

Ratmini, N.P.S. 2014. Peluang Peningkatan Kadar Seng (Zn) pada Produk Tanaman Serealia. Prosiding Seminar Nasional Lahan Suboptimal. Balai Pengkajian Teknologi Pertanian. Sumatera Selatan. $684 \mathrm{hlm}$.

Shabana, E.F., Snousy, H.H. \& Mohammad, H.Y., 2016. Effect of some Abiotic Factors on Growth, Glycerol and $\beta$-carotene Accumulation by Dunaliella bardawil. Egypt Journal. 56(3):559-571. DOI: 10.21608/EJBO.2016.2718.

Smith, D.R., Lee, R.W., Cushman, J.C., Magnuson, J.K., Tran, D. \& Polle, J.E.W. 2010. The Dunaliella salina Organelle Genomes: Large Sequences, Inflated with Intronic and Intergenic DNA. BMC Plant Biology, 10(83):1-14.

Tafreshi, A.H., \& Shariati, M. 2009. Dunaliella Biotechnology: Methods and Applications. Journal of Applied Microbiology, 107(1):14-35. DOI : 10.1111/j.1365-2672.2009.04153.x

Tripathi, B. \& Gaur, J. 2006. Physiological behavior of Scenedesmus sp. during exposure to elevated levels of $\mathrm{Cu}$ and $\mathrm{Zn}$ and after withdrawal of metal stress. Protoplasma, 229:1-9. DOI : $10.1007 / \mathrm{s} 00709-006-0196-9$

Weldy, C.S. \& Huesemann, M. 2007. Lipid Production by Dunaliella salina in Batch Culture: effects of Nitrogen Limitation and Light Intensity. Journal of Undergraduate Research. Departement of Energy, 7(7):115-122. 